\title{
Review \\ Unveiling the Impact of Antibiotics and Alternative Methods for Animal Husbandry: A Review
}

\author{
Chuen Xian Low ${ }^{1}$, Loh Teng-Hern Tan ${ }^{1,2}$, Nurul-Syakima Ab Mutalib 1,3 ${ }^{10}$, Priyia Pusparajah ${ }^{1}$, \\ Bey-Hing Goh ${ }^{4,5}$ (D), Kok-Gan Chan $6,7, * \mathbb{D}$, Vengadesh Letchumanan $1, *$ (D) and Learn-Han Lee $1, *$ (D)
}

1 Novel Bacteria and Drug Discovery (NBDD) Research Group, Microbiome and Bioresource Research Strength (MBRS), Jeffrey Cheah School of Medicine and Health Sciences, Monash University Malaysia, Selangor Darul Ehsan 47500, Malaysia; kelvinlcx@gmail.com (C.X.L.); loh.teng.hern@monash.edu (L.T.-H.T.); syakima@ppukm.ukm.edu.my (N.-S.A.M.); priyia.pusparajah@monash.edu (P.P.)

2 Clinical School Johor Bahru, Jeffrey Cheah School of Medicine and Health Sciences, Monash University Malaysia, Johor Bahru 80100, Malaysia

3 UKM Medical Molecular Biology Institute (UMBI), UKM Medical Centre, Universiti Kebangsaan Malaysia, Kuala Lumpur 50603, Malaysia

4 Biofunctional Molecule Exploratory Research Group (BMEX), School of Pharmacy, Monash University Malaysia, Selangor Darul Ehsan 47500, Malaysia; goh.bey.hing@monash.edu

5 College of Pharmaceutical Sciences, Zhenjiang University, Hangzhou 310058, China

6 Division of Genetics and Molecular Biology, Institute of Biological Sciences, Faculty of Science, University of Malaya, Kuala Lumpur 50603, Malaysia

7 International Genome Centre, Jiangsu University, Zhenjiang 212013, China

* Correspondence: kokgan@um.edu.my (K.-G.C.); vengadesh.letchumanan1@monash.edu (V.L.); lee.learn.han@monash.edu (L.-H.L.)

Citation: Low, C.X.; Tan, L.T.-H.; Ab Mutalib, N.-S.; Pusparajah, P.; Goh, B.-H.; Chan, K.-G.;

Letchumanan, V.; Lee, L.-H.

Unveiling the Impact of Antibiotics and Alternative Methods for Animal Husbandry: A Review. Antibiotics 2021, 10, 578. https://doi.org/ 10.3390/antibiotics10050578

Academic Editor: Ulf Magnusson

Received: 28 February 2021

Accepted: 9 May 2021

Published: 13 May 2021

Publisher's Note: MDPI stays neutral with regard to jurisdictional claims in published maps and institutional affiliations.

Copyright: (c) 2021 by the authors. Licensee MDPI, Basel, Switzerland. This article is an open access article distributed under the terms and conditions of the Creative Commons Attribution (CC BY) license (https:/ / creativecommons.org/licenses/by/ $4.0 /)$.

\begin{abstract}
Since the 1950s, antibiotics have been used in the field of animal husbandry for growth promotion, therapy and disease prophylaxis. It is estimated that up to $80 \%$ of the antibiotics produced by the pharmaceutical industries are used in food production. Most of the antibiotics are used as feed additives at sub-therapeutic levels to promote growth. However, studies show the indiscriminate use of antibiotics has led to the emergence of multidrug-resistant pathogens that threaten both animal health and human health, including vancomycin-resistant Enterococcus (VRE), Methicillin-resistant Staphylococcus aureus (MRSA) and carbapenem-resistant Enterobacteriaceae (CRE). This scenario is further complicated by the slow progress in achieving scientific breakthroughs in uncovering novel antibiotics following the 1960s. Most of the pharmaceutical industries have long diverted research funds away from the field of antibiotic discovery to more lucrative areas of drug development. If this situation is allowed to continue, humans will return to the pre-antibiotics era and potentially succumb to huge health and economic consequences. Fortunately, studies investigating various alternatives to antibiotics use in livestock show promising results. These alternatives include the application of bacteriophages and phage derived peptidoglycan degrading enzymes, engineered peptides, egg yolk antibodies, probiotics, prebiotics and synbiotics, as well as quorum quenching molecules. Therefore, this review aims to discuss the use of growth-promoting antibiotics and their impact on livestock and provide insights on the alternative approaches for animal husbandry.
\end{abstract}

Keywords: antibiotic; multidrug-resistant; growth-promoting; livestock; husbandry

\section{Introduction}

The discovery of penicillin by Alexander Fleming in 1928 hailed the coming of a new era in the fight against microorganisms. In the beginning, antibiotics were administered exclusively to humans as a means to combat fatal diseases. In the 1940s, during a time of rising population demand for meat and poultry, extensive research efforts in animal nutrition and feed science were conducted to increase meat production [1]. A study by Stokstad, et al. [2], which was initially designed to investigate the fermentation byproducts of Streptomyces aureofaciens as an inexpensive source of vitamin B12 for animal 
feed, discovered that an unknown ingredient in the fermented "mash" greatly increased the growth rate of chickens [2]. The scientists conducted further research and found that this mysterious component was chlortetracycline (Aureomycin), an antibiotic produced by Streptomyces aureofaciens. Additional studies later revealed that the addition of small quantities of antibiotics in animal feed was sufficient to promote growth and prevent diseases in chickens and others as well, including dairy cows, turkeys and pigs [3]. These discoveries gave birth to the commercial use of antibiotics as growth promoters in the field of animal husbandry.

In 1951, the Food and Drug Administration in the United States provided the approval for farmers to use antibiotics as a feed additive without the need for a veterinary prescription [4]. Subsequently, between 1950-1970, each European state passed its own regulations to allow the use of antibiotics in livestock feeds. The period coincided with the golden era of antibiotic discovery when scientists discovered the majority of antibiotics that we currently use today [5]. The demand for the use of antibiotics in agriculture flourished due to the lower cost of commercially available antibiotics and growing global consumption of meat. However, the uncontrolled use of antibiotics has given rise to the development of antibiotic-resistant pathogens that could potentially transfer from animals to humans [6-8]. Hence, this review aims to discuss the use of growth-promoting antibiotics and their impact on livestock, as well as discuss the potential alternatives methods for animal husbandry (Figure 1).

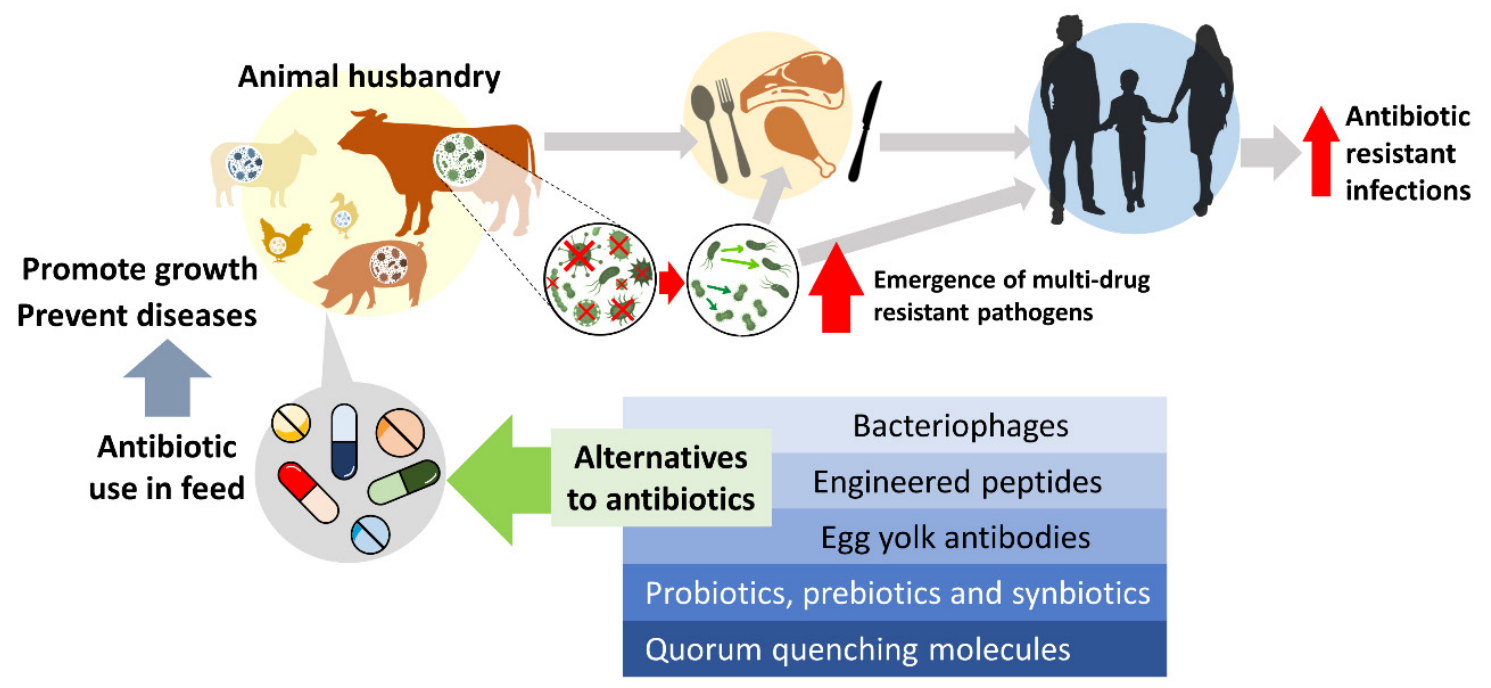

Figure 1. The effect of growth-promoting antibiotics usage in animal husbandry and the potential alternatives for livestock in disease prevention and growth promotion.

\section{How Antibiotics Function as Growth Promoters}

Several mechanisms have been proposed as possible explanations on how subtherapeutic levels of antibiotics improved growth in livestock. Gaskins, et al. [9] suggested that administration of sub-therapeutic levels of antibiotics allows animals to reduce their energy spent on maintaining their gastrointestinal commensal bacteria, thereby increasing the overall energy available for growth. This claim is supported by the findings that germ-free chickens, which were raised in isolation, did not experience enhanced growth when fed antibiotics [10]. Under normal circumstances, intestinal bacteria inhabit the intestinal tract of a host, and influence important physiological, immunological and nutritional factors, which maintain the overall health of the host [11,12]. These intestinal bacteria help animals to gain increased protection against colonisation by pathogenic bacteria, possess larger gut size, demonstrate thicker gut walls and display higher numbers of intestinal villi than that of germ-free animals [10]. Unfortunately, the bacteria also absorb nutrients, excrete metabolites, increase gut epithelial turnover and decrease fat digestibility [13]. This can lead to 
small intestine bacterial overgrowth, which is associated with malabsorption, weight loss and poor health in the animals and affect their growth.

Even at subtherapeutic levels, it was postulated that antibiotics inhibit pathogenic bacterial growth during the animal's growth phase, which improved their overall health and weight gain [14]. Antibiotics may work by reducing growth-suppressing metabolites, such as bile degradation products, through alterations in the level of bile acid-transforming enzymes-cholyltaurine hydrolase activity in the gut, which leads to increased weight gain in the animals [15]. Antibiotics improve gut barrier function by tamping down wall inflammation and improving nutrient absorption [16]. It is a well-established idea that antibiotics have an anti-inflammatory effect on inflammatory cells, which supports this theory $[17,18]$. It remains difficult to ascertain an exact mechanism of action of antibiotic growth promoters. We can conclude that antibiotic growth promoters work by influencing both gut microbiota composition and physiological processes in livestock.

\section{Transfer of Antibiotic Resistance Genes in Livestock}

The emergence of resistant bacteria is a result of the Darwinian process of natural selection, where the fittest bacteria survive and propagate themselves. The sub-therapeutic doses administered for growth promotion in animal feeds frequently create optimum selection pressures for the propagation of both pathogenic and commensal resistant bacteria in the gut of the animals by eliminating competition from non-resistant strains [19]. These organisms develop numerous methods to survive selection pressures created by antibiotics, such as antibiotic molecule deactivation by enzymes, use of efflux pumps, and development of cell wall and ribosomal modification to protect cellular targets against antibiotics [20,21]. The main modes of transmission of resistance genes from widespread antibiotic use in livestock occur either through horizontal or vertical transmission [22]. Vertical transmission occurs when the parent organism transfers its genetic material to its progeny. Horizontal transmission involves the transfer of genes through one of these three processes: transformation, transduction and conjugation.

Conjugation occurs when bacteria, which are in close proximity with one another, transfer genetic material through plasmids. This process may occur between the same or different bacterial species, and the plasmids transferred may harbour antibiotic resistance genes. Farm use of antibiotics creates the perfect stress environments for resistant bacteria in the gut to propagate and transfer resistance genes through conjugation when they come into close contact with each other. There is also strong evidence that this process of conjugation is stimulated by the presence of antibiotics [23,24]. In transduction, a virus accidentally copies host bacteria DNA, and upon infecting other bacteria, transfers that DNA into the new host. The incorporation of foreign DNA into a bacteria through this means can sometimes facilitate the transfer of antibiotic resistance genes [25]. This is supported by the identification of resistance genes in bacteriophages isolated from stool samples of both humans and livestock $[26,27]$. Natural transformation occurs when a bacterium uptakes environmental single-stranded DNA and integrates it into its chromosomes [28]. Several clinically relevant bacterial pathogens, such as Acinetobacter, Neisseria, Haemophilus, Staphylococcus, Pseudomonas, and Streptococcus, are capable of undergoing transformation to acquire antibiotic resistance genes from environmental DNA [28]. The emergence of these resistant bacteria in livestock is then transferred to humans when humans come into contact with these animals or when contaminated meat is consumed by humans [29].

Aside from directly propagating resistant bacterial strains in vivo, the antibiotics administered to livestock are not easily degraded by the animals and continue to create perfect stress environments for environmental bacteria when they are passed out of the body through urine and faeces. For instance, studies from China showed high antibiotic residue levels around the areas involved in animal husbandry activities and that $84 \%$ of the total antibiotic excretion into the environment originated from farm animals [30,31]. The extent of antibiotics released is massive, as it is estimated that 2.7 trillion pounds of animal manure, which contains antibiotics and antibiotic-resistant organisms, are generated annually in the 
United States [32]. Furthermore, these contaminated excrements eventually enter our water supplies and other elements in the food chain, causing further pollution [33]. Potential human pathogens in the environment, when exposed to these antibiotic residues, may acquire and develop antibiotic resistance and eventually cause life-threatening infections in humans.

\section{Emergence of Antibiotic-Resistant Bacteria in Livestock}

Over the years, numerous temporal studies have shown that the time of discovery of resistant bacteria corresponds with the time of introduction of a relative antibiotic in livestock [34]. In 1976, Levy, et al. [35] showed a 5-fold increase in detection of tetracyclineresistant Escherichia coli isolates from faecal samples of family members of a chicken farm, compared to their neighbours, five to six months after the farmers started introducing tetracycline in their animal feeds. Six months after cessation of tetracycline usage on the farm, the level of tetracycline-resistant microorganisms detected in the faecal samples of the family members of the farm returned to the level comparable to their neighbours. Since then, being a widespread commensal in the gut of farm animals, E. coli has been chosen as the indicator microorganism used for monitoring the antimicrobial resistance trends with Gram-negative spectra in livestock $[36,37]$. Besides studying the antimicrobial resistance in commensal $E$. coli isolated from faeces or manure of farm animals, a recent study identified that clinical E. coli isolates from diseased poultry and livestock are commonly resistant to at least three different classes of antibiotics, particularly towards tetracycline, nalidixic acid, sulfamethoxazole and ampicillin [38].

In the Netherlands, from 1982-1989, quinolone resistance in Campylobacter jejuni samples isolated from human stools and poultry products increased from $0-11 \%$ and $0-14 \%$, respectively, following the introduction of enrofloxacin for poultry use in 1987 [39]. The authors suggested this correlation because humans acquire Campylobacter jejuni infections almost exclusively from contaminated poultry products, while the resistance could not have resulted from the clinical usage of fluoroquinolones in humans as the human-to-human transmission of this infection is very rare. In the UK, a similar pattern was demonstrated. Enrofloxacin was licensed for use in poultry in 1994, and the rate of quinolone resistance in Campylobacter jejuni isolated from poultry products rose from 1\% to 10\% between 1991 and 1997 [40]. In recent years, many reports showed that Campylobacter spp. from poultry and pig farms in China had high antibiotic resistance rates, particularly towards fluoroquinolones, tetracyclines and macrolides [41-43].

The use of avoparcin, a vancomycin analogue, in many European countries as a feed additive was also attributed to the increase in vancomycin-resistant enterococci, a major medical pathogen, in both healthy humans and farm animals from 1989 to 1993 [44,45]. Ever since avoparcin was banned as a growth promoter in 1997 by European Union, the prevalence of vancomycin-resistant Enterococcus has markedly declined in food animals [46]. However, Leinweber, et al. [47] reported the first case of vancomycin-resistant Enterococcus faecium in Danish poultry farm in 2018 after the ban on avoparcin use. Furthermore, vancomycin resistance genes were detected in the faeces of pigs from several Danish pig farms, suggesting pig faeces as a potential reservoir for the transfer of antibiotic resistance determinants to zoonotic pathogens [48].

Up till today, it is still a debate whether the emergence and dissemination of antibioticresistant bacteria that infect humans is a consequence of intensive use of these antibiotics in the farms [49]. For instance, ciprofloxacin-resistant Escherichia coli isolates from both poultry and human samples have been found to share similar molecular profiles, which further suggests that drug-resistant human pathogens can originate from farm animals [50]. On the contrary, a study by Graziani, et al. [51] demonstrated that both ciprofloxacinsusceptible and -resistant E. coli strains of avian origin were phylogenetically distinct from the ciprofloxacin-resistant E. coli strains from humans. Nevertheless, the role of farm animals in the emergence and dissemination of antibiotic-resistant bacteria to humans remains controversial and elusive. This is because of the complexity of the transmission 
pathways of the antibiotic resistance genes involved in the spread between livestock-tohuman, human-to-human and human-to-livestock [52]. Having said that, a recent metaanalysis suggested that to unravel the complex transmission dynamics of resistant bacteria and their antibiotic resistance determinants between humans and food animals requires much effort by combining the genomic data analysis and epidemiological approaches [49].

\section{Consequences of Antibiotic Resistance}

Shortly after the widespread use of antibiotics as growth promoters in livestock in the 1950s, there were multiple reports on outbreaks due to drug-resistant pathogens in both humans and farm animals across various countries $[53,54]$. Data from the World Health Organization showed that some of the common resistant bacteria include Escherichia coli, Klebsiella pneumoniae, Salmonella spp., Streptococcus pneumoniae and Staphylococcus aureus are, in fact, common pathogens of both humans and livestock [55]. The situation is further complicated by the fact that resistance against a particular antibiotic group can offer crossresistance to another antibiotic group [56,57]. Today, infections with antibiotic-resistant microorganisms lead to significant healthcare and economic losses, and are associated with extended hospital stays, higher mortality rates and greater risk of complications [58-60]. The United States Centre for Disease Control (CDC) estimated that in 2019, more than 2.8 million infections and 35,000 deaths were caused by multidrug-resistant infections in the United States [6]. If no further action is taken to address antimicrobial resistance, it has been projected that the number of deaths due to infections caused by multidrug-resistant bacteria could increase up to 10 million yearly in 2050 globally [61,62]. Subsequently, an estimated 1.1-3.8\% losses in the annual gross domestic product would be expected by 2050, and pushing 28 million people towards extreme poverty [63]

In order to treat infections by resistant bugs, alternative antibiotics, which usually have inadequate safety profiles, need to be used. For example, colistin, an antibiotic of last resort, is effective in treating highly resistant Pseudomonas aeruginosa and Acinetobacter baumannii infections; however, it causes severe renal deterioration and failure in patients [64]. It is even more worrying that the therapeutic use of colistin may not last long, as plasmidmediated resistance against this drug was discovered in Escherichia coli isolates derived from pigs in 2016 [65]. If all of our therapeutic antibiotics are eventually rendered useless in the face of resistant bugs, humanity will return to the pre-antibiotic era, where even minor cuts can become infected and lead to catastrophic consequences [66].

\section{Use of Antibiotics in Livestock Today}

Worldwide meat consumption is on the rise, and according to the 2013 statistics from the United Nations Food and Agriculture Organisation (FAO), the most consumed meat worldwide is pork, at 112 million tonnes annually, followed by poultry, at 104 million tonnes annually [67]. As a means of coping with the rising demand for food, the use of antibiotics as growth promoters and feed enhancers were put into practice. In 2014, as high as $80 \%$ of the antibiotics produced and sold in the United States were used in animals to promote growth and prevent infections [68]. However, the uncontrolled application of these antibiotics at subtherapeutic doses in food animals, such as for purposes of growth promotion, has significantly contributed to the escalating antimicrobial resistance [69-71].

Today, countries with strict regulation have already banned the use of antibiotics as growth promoters. As early as 2006, the European Union banned the use of all in-feed antibiotics [72]. In 2017, the United States Food and Administration (FDA) imposed new regulations to limit antibiotic use in livestock, where clinically important antibiotics are banned for purposes of growth promotion in animal husbandry [73]. Although many of the world's top meat-producing countries have banned the use of antibiotics as growth promoters in livestock, countries such as China, Russia and India still allow farmers to use the antibiotic growth promoter in livestock [74]. Hence, it is imperative to implement alternatives to the use of antibiotics in major farm animals to curtail the rising antimicrobial resistance and its impact on human morbidity and mortality. 


\section{Alternative Methods for Animal Husbandry}

\subsection{Bacteriophage Therapy and Phage-Derived Peptidoglycan Degrading Enzymes}

Bacteriophages are bacteria-infecting viruses with highly specific target populations [75,76]. The serendipitous discovery of bacteriophages is akin to that of many major scientific breakthroughs. The first documented paper on bacteriophage is attributed to F.W. Twort in 1915. In his attempt to describe a medium that was able to culture viruses, he observed that micrococcus, an accidental growth in his agar culture inoculated with vaccinia virus, demonstrated unusual properties which indicate infection [77]. Initially, this discovery did not garner much interest, and Twort was unable to experiment further on his findings due to financial difficulties. Subsequently, in 1917, bacteriologist Felix d'Herelle, detailed how a filtrable agent, which he correctly deduced to be a virus, was infecting and killing the culture of Shiga dysentery bacillus [78]. His paper galvanised the scientific community's interest into the application of bacteriophages in controlling bacterial pathogens.

Experimental in-vivo studies on the administration of bacteriophage therapies were successful in achieving a consistent reduction of Campylobacter jejuni populations in broiler chickens $[79,80]$. Chinivasagam and collegaues demonstrated the use of phage cocktails to control Campylobacter in broiler chicken at the farm. The bacteriophages cocktails that were selected to target $C$. jejuni and C. coli. The phages were administrated via oral gavage to 47 day old birds for $24 \mathrm{~h}$ prior to slaughter. The researcher found that the phage cocktails were effective at reducing Campylobacter levels in the market ready broilers. Nevertheless, there were a few birds in farm B showed a low phage titres, and the authors recommended to increase the treatment for over $24 \mathrm{~h}$ to ensure continuous phage replication for biocontrol of Campylobacter in-vivo [81]. Richards, et al. [82] carried out a study in broiler chicken to determine the efficacy of a two-phage cocktail against $C$. jejuni. The study revealed a significant reduction in caecal counts of the bacterium after two days of treatment, and without affecting the microbiota of the chicken. The bacteriophage administration is proven to be safe compared to the broad bactericidal effects of antibiotics on the animal gut microbiome.

In the context of Salmonella, studies have reported the use of anti-Salmonella phage cocktail to reduce Salmonella colonisation up to $99.9 \%$ in the tonsils, ileum and cecum of pigs [83,84]. Vaz, et al. [85] studied the timing effect of phage cocktail (3 lytic phages) therapy against $S$. enteritidis in broiler chickens. After bacterial inoculations on the day of hatching, the chicks received the phage treatments at two intervals, early (6-10 days) and late (31-35 days). The researchers reported both in vivo trials displayed a lower in intestinal S. enteritidis counts when compared to the control group and higher efficacy in the late phage application. They concluded that multiple phage therapy could enhance the phage ability to control intestinal S. enteritidis colonisation in broilers [85]. Recently, a study assessed the efficacy of a patented phage SalmoFREE ${ }^{\circledR}$ against Salmonella in broiler chicken on a commercial farm via the animal drinking water. The phage SalmoFREE ${ }^{\circledR}$ has successfully reduced Salmonella counts on day 34 of treatment compared to the control group. SalmoFREE ${ }^{\circledR}$ had no adverse effect on the broiler chickens and the production parameters used [86].

Bacteriophage therapy has also been proven to be effective against colibacillosis and clostridiosis in poultry $[86,87]$. One study showed that a combination of three lytic phages which were fed to naturally avian pathogenic Escherichia coli infected chicken resulted in a decrease in the mortality levels, while another study reported that the mortality rate from Clostridium perfringens associated necrotic enteritis decreased by $92 \%$ in chickens which were given a multivalent bacteriophage cocktail $[88,89]$. Aside from its use as an antimicrobial agent, bacteriophage therapy also exhibit growth-promoting effects when given to livestock. This was evident by an increased average daily weight gain and enhanced gut villi morphology in pigs that were fed with bacteriophage cocktail in comparison to the control group [90].

The development of an effective bacteriophage therapy does pose challenges for researchers. It has been demonstrated that pathogenic bacteria in poultry exhibit the ability 
to undergo genomic rearrangement between various phenotypes as a defence mechanism against the environmental selection pressure posed by bacteriophages, giving rise to bacteriophage-insensitive mutants [91,92]. In addition, naturally occurring bacteriophages in the environment may contain reservoirs of antibiotic-resistant genes (ARG) and mediate the transfer of these genes between bacteria $[93,94]$. However, this is still a subject of debate among researchers, as recent studies suggested that ARGs were overestimated in phages, as shown by the vast differences in predicted versus known ARGs and matches of genomes to proteins unrelated to antibiotic resistance when exploratory thresholds were utilised by researchers in phage genomic analysis $[95,96]$.

Phage-derived peptidoglycan degrading enzymes, namely the virion-associated lysins (VALs) and endolysins, have also been explored as a potential new class of antibacterial agent $[97,98]$. Numerous in-vitro studies have proved their effectiveness against multi-drug resistant organisms, such as MRSA and VRE organisms [99,100]. Although it was initially challenging to target Gram-negative organisms due to the presence of an outer membrane surrounding the peptidoglycan wall target, researchers successfully modified endolysins by combining them with a polycationic nonapeptide to produce Artilysins which are bactericidal towards Pseudomonas aeruginosa and Acinetobacter baumanni species [101]. As for in vivo experiments, mice models were largely utilised, where preliminary results showed the effectiveness of endolysins against pathogenic organisms when given during the early stages of infection [102]. It is anticipated that future research efforts will allow VAL to be used as an antimicrobial agent and explore its potential as a growth promoter. Another interesting finding is that peptidoglycan-degrading enzymes derived from certain bacteriophages are highly thermostable. VAL from the P. aeruginosa phiKMV bacteriophage retained $>20 \%$ of activity after $2 \mathrm{~h}$ at $100{ }^{\circ} \mathrm{C}$, while endolysins from multiple thermophilic Geobacillus bacteriophage strains were shown to be effective against strains of C. perfringens known to cause necrotic enteritis in the poultry and swine $[103,104]$. This trait is highly desirable as this allows phage-derived peptidoglycans to remain effective even after factory processing as many of commercial animal feeds undergo heat treatment during production.

\subsection{Egg Yolk Antibodies (EYA)}

Egg yolk antibodies is a form of passive immunity offered by the hen to their offspring. Kemplerer first described the transfer of immunoglobulin against the tetanus toxin from hen to chick in 1893 [105]. This discovery leads to a significant interest in the extraction and utilisation of these antibodies to target specific pathogens for use in both animals and livestock.

Out of the various immunoglobulins produced by chickens, $\operatorname{Ig} Y$ is one of the major antibodies that has garnered significant scientific interest. It is present in significant quantities in the egg yolk instead of the other immunoglobulin types present only in small amounts [106]. It is hypothesised that large scale production of IgY is possible, as an average hen would lay enough eggs to produce $100 \mathrm{~g}$ of antibodies per year [107]. This production rate of IgY antibodies can be further increased through the utilisation of hens from high antibody-producing genotypes [108].

There is a wide range of benefits of $\operatorname{IgY}$ antibody. Immunoglobulin $\mathrm{Y}(\operatorname{Ig} \mathrm{Y})$ and the functional counterpart of mammalian IgG are excellent candidates alternatively to antibiotics for preventive and therapeutic against bacteria and virus $[109,110]$. IgY is also effective in providing protection against a wide range of gastrointestinal pathogens in humans and animals. The IgY antibodies have no harmful effect, toxic residue, disease resistance in animals, and does not cross-act with the mammalian immune system [111]. These antibodies can also be used in animal supplements [112].

A study on the effectiveness of IgY antibodies administration against Salmonella spp. infections in poultry showed mixed results. Although the inhibition of Salmonella enteritidis growth was demonstrated in vitro, the administration of extracted egg yolk antibodies specific to $S$. enteritidis did not significantly reduce gut colonisation when these antibodies 
were fed directly to the chickens $[107,113]$. However, in another study, investigators showed a reduction in the rate of $S$. enteritidis contamination in eggs laid by infected hens that were fed with antibody-containing whole egg powder [114].

Karamzadeh-Dehaghani, et al. [111] studied the effectiveness of IgY antibodies against enterotoxigenic Escherichia coli $\mathrm{K} 99$ in vitro. The results showed specific IgY antibodies had the bacterial inhibiting growth at $200 \mathrm{mg} / \mathrm{mL}$. Vandeputte and colleagues studied the reduction of Campylobacter jejuni colonisation in broiler chickens after supplemented with IgY antibodies. The in vivo study resulted in a significant reduction in C. jejuni counts in the infected birds compared to control broilers [115]. In summary, the results from these in vitro and in vivo studies demonstrated the effectiveness and potential use of IgY antibodies as a replacement for antibiotics in farms.

One notable challenge of the widespread use of immunoglobulins to replace antibiotics is that the pathogen-specific egg yolk immunoglobulins produced do not confer broadspectrum protection against the various diseases affected by chickens, as opposed to antibiotics [116]. Manufacturing issues, such as the lack of ideal extraction methods and storage instability of egg yolk immunoglobulins, would need to be addressed before large scale production can commence [117]. It is also estimated that the overall cost of egg yolk immunoglobulins would be higher compared to antibiotics [118].

\subsection{Engineered Peptides}

Antimicrobial peptides are amphipathic cationic peptides that are produced endogenously by plants and animals as part of the innate defence system $[119,120]$. Examples of antimicrobial peptides discovered include bacteriocins, defensins, tachyplesins, $\beta$-defensins, protegrins and insect defensins [121,122]. These antimicrobial peptides possess broadspectrum activity against both Gram-positive and Gram-negative bacteria, exhibit lower minimal inhibitory concentrations compared to antibiotics and offer synergistic effects to combat multidrug-resistant pathogens when administered with antibiotics [123-125].

Numerous studies from China showed that antimicrobial peptides provide growthenhancing and immune-boosting effects when they are fed to chickens [126,127]. Bacteriocins from various microorganisms have also shown promising results in inhibiting the growth of Clostridium perfringens, a major cause of necrotic enteritis in broiler chickens, in both in vivo and in vitro studies [128-130]. The use of animal peptides, such as spray-dried plasma, has been shown to increase the growth rate of pigs by improving their immunity [131]. Feeding 5-6\% of hydrolysed porcine small intestine, a by-product from the extraction of heparin, to post-weaned pigs for two weeks has also shown an increase in feed intake and growth rate, though the mechanisms of action remain unclear. Some of the challenges of widespread use of peptides include the high production cost, loss of efficacy under physiological salt and serum conditions, and potential toxicity issues [132].

A recent study by Daneshmand, et al. [133] revealed the effects of cLFchimera peptide (a recombinant antimicrobial peptide, AMP) in broiler chickens under necrotic enteritis (NE) challenge. The results showed cLFchimera peptide ameliorated NE-related intestinal lesions, reduced mortality and rehabilitated the jejunal villi morphology in NE challenged birds. While the antibiotic non-selectively reduced the count of bacteria, cLFchimera peptide restored microflora balance in the ileum of challenged broiler chickens. The authors concluded that cLFchimera could be a promising candidate to substitute growth promoter antibiotics in farms [133].

The effectiveness of a novel apidaecin Api-PR 19 produced by engineered prokaryotic expression bacteria as a substitute for antibiotic growth promoters was studied by $\mathrm{Wu}$, et al. [125]. The results demonstrated that broilers fed with Api-PR ${ }_{19}$ supplementation significantly increase the organ index of the bursa of Fabricius and subtype H9 antibody level in broiler chickens. The antibacterial effect of $A$ pi-PR 19 in vitro and in vivo revealed that Api-PR 19 inhibited the growth of Escherichia coli and Campylobacter jejuni, without disturbing the beneficial bacteria and microbiota in broilers [125]. 
Another interesting study by Li, et al. [134] showed that insect defensins are promising candidates against antibiotic-resistant Staphylococcus aureus. A variant designed from insect defensin $\mathrm{DLP}_{4}, \mathrm{ID}_{13}$ exhibited strong antibacterial activity at low MIC values of $4-8 \mu \mathrm{g} / \mathrm{mL}$ to Gram-positive pathogens (S. aureus, S. epidermidis, S. pneumoniae, S. suis), which were lower than those of $\mathrm{DLP}_{4}$, and cytotoxicity of $\mathrm{ID}_{13}(71.4 \%$ viability) was less than that of $\mathrm{DLP}_{4}\left(63.8 \%\right.$ viability). The authors concluded that $\mathrm{ID}_{13}$ could be a promising peptide antibiotic agent for therapeutic applications in farms [134].

In summary, the studies above unveiled the potential of antimicrobial peptides as an alternative to antibiotic growth promoters in animal husbandry. These antimicrobial peptides can be produced by bacteria, insects, amphibians, fishes, plant and mammals, as well as by in vitro microbial fermentation using gene engineering strains [135]. They have natural antibiotics properties, low tendency to develop resistance by bacteria, and does not affect the host microbiota. The antimicrobial peptides should be applied in the animal husbandry, thus reducing the effects of antibiotic growth promoters.

\subsection{Quorum-Sensing \& Quorum Quenching}

Quorum sensing refers to the process in which cells communicate by producing and detecting extracellular cell signalling molecules known as autoinducers (AI) and alter their gene expression in response to the cell population density [136,137]. It was first described in 1970 by Nealson, et al. [138] when his research team discovered that the bioluminescent bacteria, Photobacterium fischeri, secreted the enzyme luciferase in a huge amount during a period of exponential bacterial growth. Over time, it was discovered that pathogenic bacteria also express virulence factors, biofilm formation and drug-resistant behaviours through the process of quorum sensing $[139,140]$.

Quorum quenching refers to a process in which prokaryotes and eukaryotes disrupt the signals involved in quorum sensing. By utilising quorum sensing inhibitors or quorum quenching enzymes, undesirable traits of bacterial behaviour can be controlled [140]. This novel approach to controlling the growth of bacteria is appealing, as the bacteria are not killed-unlike when they are challenged with antibiotics - and resistance is less likely to develop within the bacteria [140].

N-acyl-L-homoserine lactones (AHLs) are regulatory ligands in many Gram-negative organisms that control the expression of virulence genes through regulatory proteins, which are known as LuxR-type proteins. Several quorum quenching molecules, which target AHLs-dependent quorum sensing, have been extensively studied in recent years. The halogenated furanones, which are derived from marine alga Delisea pulchra, have been shown to destabilise LuxR activity [141,142]. The enzymes encoded by the aii $A$ gene present in Bacillus sp. 240B1 have also been effective in the inactivation of AHLs [143,144]. Similar AHL-lactonases have also been effective in inhibiting biofilm formation by Vibrio parahaemolyticus DAHP1 on a coverslip assay [145]. Furthermore, in vivo studies involving zebrafish showed that fish fed with these enzymes displayed significant protection against Aeromonas hydrophila infections [146]. Although there are no such studies conducted on livestock animals, it is anticipated that these molecules would produce similar bacterial inhibiting effects, which would replace the use of antibiotics.

The phosphotriesterase-like lactonase (PLL) family of enzymes are another group of quorum quenching molecules that target AHL-mediated quorum sensing systems, which have garnered significant interest $[147,148]$. The most notable member of this family is the SsoPox enzyme, which was isolated from the hyperthermophilic Sulfolobus solfataricus [149]. Enzymes from this family are highly attractive for use in biotechnology, as they are found to be highly tolerant of heat, protease degradation, organic solvents and surfactants $[150,151]$. It is anticipated that the stability of these molecules allows them to be effectively incorporated into materials such as paints, coatings and polymers, which can be used to line the housing areas of livestock to decrease the exposure of the animals to pathogenic bacteria and reduce the need for antibiotics for prophylactic use [140]. 


\subsection{Probiotics, Prebiotics and Synbiotics}

It has long been an established practice in animal husbandry and aquaculture to include probiotics, prebiotics and synbiotics into animal feeds to promote growth [152]. As the beneficial effects and excellent safety profile of these additives have been welldocumented, it is crucial to create more efficient and cost-effective growth promoters as alternatives to antibiotic growth promoters in animal feed, especially in countries where bans have not yet been implemented.

Probiotics are defined as a live microbial feed supplement that beneficially affects the host animal by improving the intestinal microbial balance [153]. Probiotics are known to stimulate not only the growth of host animals but also inhibit the proliferation of harmful pathogenic bacteria [154]. Examples of probiotics commonly administered to livestock include genus Bacillus, Enterococcus, and Saccharomyces yeast [155]. The administration of Bacillus sp. has been found to reduce Clostridium and Salmonella populations in poultry significantly [156].

Animals fed with Bacillus subtilis demonstrate increased weight gain, improved feeding and enhanced gut nutrient absorption; the quality of meat and eggs produced are also enhanced [157]. Chicks that were fed Lactobacillus acidophilus and Streptococcus faecium probiotics had a $70 \%$ reduction in faecal shedding and $27 \%$ in jejunal colonisation of Campylobacter jejuni [158]. One of the major challenges of probiotics includes the fear that they may facilitate the transfer of antibiotic-resistant genes as they interact with possible pathogenic bacteria in the gut. Bacillus subtilis has been found to harbour genes, such as the aadD2 gene, bla (BCL-1) gene, cat (BCL) gene, which confer resistance against aminoglycosides, beta-lactams, macrolides and chloramphenicol [159-161].

Prebiotics are non-digestible food ingredients that exert a positive effect through their selective metabolism mechanism as they pass through the intestinal tract [162]. Examples of prebiotics include oligosaccharides, acidifiers, protein hydrolysates, plant extracts and many more. They have been shown to improve immune function, anti-viral activities and proliferate certain intestinal bacteria. The major challenges of prebiotics include gastrointestinal side effects (diarrhoea, bloating) and the high production cost [163].

Synbiotics are preparations containing a combination of probiotics and prebiotics. Broilers fed with a combination of probiotics (Bacillus licheniformis, Bacillus subtilis and Clostridium butyricum) and prebiotics (xylooligosaccharide and yeast cell wall) yielded greater breast mass and lower abdominal fat [164]. Supplementation of feeds with Biomin ${ }^{\circledR} \mathrm{IMBO}$ (combination of Enterococcus faecium, cell wall fragments, fructooligosaccharides and phycophytic substances) significantly increased weight gain in chickens [165]. Numerous studies have also been carried out to investigate the beneficial effects of synbiotics when injected in-ovo. It was found that an in-ovo injection of a combination of Lactococcus lactis, galactooligosaccharides and fructan significantly increased the final body weight of the chickens at day 34 [166]. Potential challenges to the use of synbiotics include the high costs of production [167].

\section{Conclusions and Future Perspective}

In conclusion, the complete removal of antibiotics administration in livestock is impossible at this stage, as it would lead to severe disruptions in worldwide meat production. A feasible solution to this age-old problem would focus on utilising alternative agents which are both effective and economical for disease prevention and growth promotion, while retaining the use of antibiotics in treating animal diseases upon veterinary prescriptions. This is a viable option, as it has been shown that with controlled use of antibiotics in livestock, resistance levels can decrease to original parameters in a particular area.

It is exciting to note that apart from the alternatives to antibiotics highlighted above, there are several cutting-edge technologies that are currently being investigated. The sporeproducing properties of Bacillus spp. have been explored for use in the field of nanobiotechnology. By altering the genes encoding for the spore-coat proteins in Bacillus spp., various peptides have been successfully expressed on the surfaces of the spores produced by the genetically-modified bacteria. Upon ingestion of the bacteria, these peptide-containing 
spores were produced in vivo, and can be designed to exhibit a huge range of properties, such as the ability to adsorb heavy metals, improve enzymatic activity and confer specific immunity [168-170]. This may potentially remove the use of antibiotics as growth promoters and in disease prophylaxis in livestock in the future. Furthermore, there is significant interest in the development of CRISPR-Cas9 gene-editing technology, which offers the possibility to reverse antibiotic resistance in specific pathogenic bacteria [171]. The highly specific nature of CRISPR guide RNAs allows for programmed targeting of certain chromosomal and virulence genes, which negates the need to use broad-spectrum antibiotics to treat diseases in livestock [172]. Moreover, a new method of culturing soil bacteria, unlike the conventional Waxman approach, was discovered recently, which led to the discovery of teixobactin, an antibiotic with a novel mechanism of action [173]. This presents an exciting opportunity for the future discovery of novel antibiotics, as previously uncultivable soil bacteria account for $99 \%$ of all bacterial species in the environment [173]. We can then reserve the use of these novel antibiotics for therapeutic usage in clinical settings while maintaining the controlled use of antibiotics as growth promoters in livestock to meet agricultural production demands. However, we must not be overly optimistic, as resistance towards novel antibiotics tends to surface soon after antibiotic introduction for widespread use. Nevertheless, the judicious use of existing antibiotics in livestock is highly warranted at this stage, as alternative methods require time to gain the appropriate licensing from regulatory bodies before they can be introduced into the market.

Author Contributions: C.X.L., L.T.-H.T., V.L. and L.-H.L. performed the literature search and critical data analysis. C.X.L. performed the manuscript writing. K.-G.C., L.T.-H.T., N.-S.A.M., P.P., B.-H.G., V.L. and L.-H.L. provided conceptualize, technical support, and proofreading. V.L. and L.-H.L. set up this review writing project. All authors have read and agreed to the published version of the manuscript.

Funding: This work is supported by University of Malaya Research Grant (FRGS Grant No: FP0222018A) awarded to K-GC, Fundamental Research Grant Scheme (FRGS/1/2019/SKK08/MUSM/02/7) awarded to L-HL, and SEED Funding from Microbiome and Bioresource Research Strength (MBRS), Jeffrey Cheah School of Medicine and Health Sciences (Vote Number: MBRS/JCSMHS/02/2020).

Acknowledgments: Professor Shajahan Yasin, and Head of School, Jeffrey Cheah School of Medicine and Health Sciences, Monash University Malaysia.

Conflicts of Interest: The authors declare no conflict of interest.

\section{References}

1. Moore, P.; Evenson, A.; Luckey, T.; McCoy, E.; Elvehjem, C.; Hart, E. Use of sulfasuxidine, streptothricin, and streptomycin in nutritional studies with the chick. J. Biol. Chem. 1946, 165, 437-441. [CrossRef]

2. Stokstad, E.; Jukes, T.H.; Pierce, J.; Page, A.; Franklin, A. The multiple nature of the animal protein factor. J. Biol. Chem. 1949, 180, 647-654. [CrossRef]

3. Jukes, T.H. Antibiotics in Nutrition; Medical Encyclopedia, Inc.: New York, NY, USA, 1955; p. 128.

4. Jones, F.; Ricke, S. Observations on the history of the development of antimicrobials and their use in poultry feeds. Poult. Sci. 2003, 82, 613-617. [CrossRef]

5. Lewis, K. Recover the lost art of drug discovery. Nat. Cell Biol. 2012, 485, 439-440. [CrossRef]

6. CDC. Antibiotic Resistance Threats in the United States, 2019; U.S. Department of Health and Human Services, CDC: Atlanta, GE, USA, 2019; 139p.

7. Loo, K.; Letchumanan, V.; Law, J.W.; Pusparajah, P.; Goh, B.; Ab Mutalib, N.; He, Y.; Lee, L. Incidence of antibiotic resistance in Vibrio spp. Rev. Aquac. 2020, 12, 2590-2608. [CrossRef]

8. Letchumanan, V.; Ab Mutalib, N.-S.; Wong, S.H.; Chan, K.-G.; Lee, L.-H. Determination of antibiotic resistance patterns of Vibrio parahaemolyticus from shrimp and shellfish in Selangor, Malaysia. Prog. Microbes Mol. Biol. 2019, 2, 2. [CrossRef]

9. Gaskins, H.R.; Collier, C.T.; Anderson, D.B. Antibiotics as growth promotants:mode of action. Anim. Biotechnol. 2002, 13, $29-42$. [CrossRef]

10. Coates, M.E.; Davies, M.K.; Kon, S.K. The Effect of Antibiotics on the Intestine of the Chick. Br. J. Nutr. 1955, 9, 110-119. [CrossRef] [PubMed]

11. Gaskins, H.R. Intestinal bacteria and their influence on swine growth. In Swine Nutrition, 2nd ed.; Apple Academic Press: Boca Raton, FL, USA, 2000; pp. 585-608. 
12. Lau, A.W.Y.; Tan, L.T.-H.; Ab Mutalib, N.-S.; Wong, S.H.; Letchumanan, V.; Lee, L.-H. The chemistry of gut microbiome in health and diseases. Prog. Microbes Mol. Biol. 2021, 4, 4. [CrossRef]

13. Dibner, J.J.; Richards, J.D. Antibiotic growth promoters in agriculture: History and mode of action. Poult. Sci. 2005, 84, 634-643. [CrossRef]

14. Kim, J.; Guevarra, R.B.; Nguyen, S.G.; Lee, J.-H.; Jeong, D.K.; Unno, T. Effects of the antibiotics growth promoter tylosin on swine gut microbiota. J. Microbiol. Biotechnol. 2016, 26, 876-882. [CrossRef] [PubMed]

15. Feighner, S.D.; Dashkevicz, M.P. Subtherapeutic levels of antibiotics in poultry feeds and their effects on weight gain, feed efficiency, and bacterial cholyltaurine hydrolase activity. Appl. Environ. Microbiol. 1987, 53, 331-336. [CrossRef]

16. Oh, S.; Lillehoj, H.S.; Lee, Y.; Bravo, D.; Lillehoj, E.P. Dietary antibiotic growth promoters down-regulate intestinal inflammatory cytokine expression in chickens challenged with LPS or co-infected with Eimeria maxima and Clostridium perfringens. Front. Vet. Sci. 2019, 6, 420. [CrossRef]

17. Bersani, C.; Bertoletti, R.; Colombo, M.L.; Merlini, C.; Uccelli, M.; Fietta, A.; Grassi, G.G. In vitro and ex vivo influence of rifamycins on human phagocytes. Chemioter. Int. J. Mediterr. Soc. Chemother. 1987, 6, 420-425.

18. Broek, P.J.V.D. Antimicrobial drugs, microorganisms, and phagocytes. Clin. Infect. Dis. 1989, 11, 213-245. [CrossRef]

19. Lukášová, J.; Šustáčková, A. Enterococci and antibiotic resistance. Acta Vet. Brno 2003, 72, 315-323. [CrossRef]

20. Alekshun, M.N.; Levy, S.B. Molecular mechanisms of antibacterial multidrug resistance. Cell 2007, 128, 1037-1050. [CrossRef] [PubMed]

21. Kemung, H.M.; Tan, L.T.-H.; Khan, T.M.; Chan, K.-G.; Pusparajah, P.; Goh, B.-H.; Lee, L.-H. Streptomyces as a prominent resource of future anti-MRSA drugs. Front. Microbiol. 2018, 9, 2221. [CrossRef]

22. Lerminiaux, N.A.; Cameron, A.D. Horizontal transfer of antibiotic resistance genes in clinical environments. Can. J. Microbiol. 2019, 65, 34-44. [CrossRef]

23. Zhang, P.-Y.; Xu, P.-P.; Xia, Z.-J.; Wang, J.; Xiong, J.; Li, Y.-Z. Combined treatment with the antibiotics kanamycin and streptomycin promotes the conjugation ofEscherichia coli. FEMS Microbiol. Lett. 2013, 348, 149-156. [CrossRef]

24. Al-Masaudi, S.B.; Day, M.J.; Russell, A.D. Effect of some antibiotics and biocides on plasmid transfer inStaphylococcus aureus. J. Appl. Bacteriol. 1991, 71, 239-243. [CrossRef]

25. Muniesa, M.; Colomer-Lluch, M.; Jofre, J. Potential impact of environmental bacteriophages in spreading antibiotic resistance genes. Futur. Microbiol. 2013, 8, 739-751. [CrossRef]

26. Quirós, P.; Colomer-Lluch, M.; Martínez-Castillo, A.; Miró, E.; Argente, M.; Jofre, J.; Navarro, F.; Muniesa, M. Antibiotic resistance genes in the bacteriophage DNA fraction of human fecal samples. Antimicrob. Agents Chemother. 2013, 58, 606-609. [CrossRef]

27. Colomer-Lluch, M.; Imamovic, L.; Jofre, J.; Muniesa, M. Bacteriophages carrying antibiotic resistance genes in fecal waste from cattle, pigs, and poultry. Antimicrob. Agents Chemother. 2011, 55, 4908-4911. [CrossRef]

28. Johnston, C.; Martin, B.; Fichant, G.; Polard, P.; Claverys, J.-P. Bacterial transformation: Distribution, shared mechanisms and divergent control. Nat. Rev. Genet. 2014, 12, 181-196. [CrossRef]

29. Bogaard, A.E.V.D. Epidemiology of resistance to antibiotics Links between animals and humans. Int. J. Antimicrob. Agents 2000, 14, 327-335. [CrossRef]

30. Zhang, Q.-Q.; Ying, G.-G.; Pan, C.-G.; Liu, Y.-S.; Zhao, J.-L. Comprehensive evaluation of antibiotics emission and fate in the river basins of China: Source analysis, multimedia modeling, and linkage to bacterial resistance. Environ. Sci. Technol. 2015, 49, 6772-6782. [CrossRef]

31. Zhu, Y.-G.; Johnson, T.A.; Su, J.-Q.; Qiao, M.; Guo, G.-X.; Stedtfeld, R.D.; Hashsham, S.A.; Tiedje, J.M. Diverse and abundant antibiotic resistance genes in Chinese swine farms. Proc. Natl. Acad. Sci. USA 2013, 110, 3435-3440. [CrossRef]

32. Lessing, A. Killing us softly: How sub-theraputic dosing of livestock causes drug-resistant bacteria in humans. BC Envtl. Aff. Law Rev. 2010, 37, 463.

33. Boonsaner, M.; Hawker, D.W. Evaluation of food chain transfer of the antibiotic oxytetracycline and human risk assessment. Chemosphere 2013, 93, 1009-1014. [CrossRef] [PubMed]

34. Teillant, A.; Brower, C.H.; Laxminarayan, R. Economics of antibiotic growth promoters in livestock. Annu. Rev. Resour. Econ. 2015, 7,349-374. [CrossRef]

35. Levy, S.B.; Fitzgerald, G.B.; Macone, A.B. Changes in intestinal flora of farm personnel after introduction of a tetracyclinesupplemented feed on a farm. N. Engl. J. Med. 1976, 295, 583-588. [CrossRef]

36. Caruso, G. Antibiotic resistance in Escherichia coli from farm livestock and related analytical methods: A review. J. AOAC Int. 2018, 101, 916-922. [CrossRef]

37. Hesp, A.; Veldman, K.; Van Der Goot, J.; Mevius, D.; Van Schaik, G. Monitoring antimicrobial resistance trends in commensal Escherichia coli from livestock, the Netherlands, 1998 to 2016. Eurosurveillance 2019, 24, 1800438. [CrossRef]

38. Yassin, A.K.; Gong, J.; Kelly, P.; Lu, G.; Guardabassi, L.; Wei, L.; Han, X.; Qiu, H.; Price, S.; Cheng, D.; et al. Antimicrobial resistance in clinical Escherichia coli isolates from poultry and livestock, China. PLoS ONE 2017, 12, e0185326. [CrossRef] [PubMed]

39. Endtz, H.P.; Ruijs, G.J.; Van Klingeren, B.; Jansen, W.H.; Van Der Reyden, T.; Mouton, R.P. Quinolone resistance in campylobacter isolated from man and poultry following the introduction of fluoroquinolones in veterinary medicine. J. Antimicrob. Chemother. 1991, 27, 199-208. [CrossRef] [PubMed]

40. Gaunt, P.N.; Piddock, L.J.V. Ciprofloxacin resistant Campylobacter spp. in humans: An epidemiological and laboratory study. J. Antimicrob. Chemother. 1996, 37, 747-757. [CrossRef] 
41. Tang, M.; Zhou, Q.; Zhang, X.; Zhou, S.; Zhang, J.; Tang, X.; Lu, J.; Gao, Y. Antibiotic resistance profiles and molecular mechanisms of Campylobacter from chicken and pig in China. Front. Microbiol. 2020, 11, 592496. [CrossRef] [PubMed]

42. Ma, L.; Wang, Y.; Shen, J.; Zhang, Q.; Wu, C. Tracking Campylobacter contamination along a broiler chicken production chain from the farm level to retail in China. Int. J. Food Microbiol. 2014, 181, 77-84. [CrossRef]

43. Qin, S.-S.; Wu, C.-M.; Wang, Y.; Jeon, B.; Shen, Z.-Q.; Wang, Y.; Zhang, Q.; Shen, J.-Z. Antimicrobial resistance in Campylobacter coli isolated from pigs in two provinces of China. Int. J. Food Microbiol. 2011, 146, 94-98. [CrossRef] [PubMed]

44. Klare, I.; Badstübner, D.; Konstabel, C.; Böhme, G.; Claus, H.; Witte, W. Decreased incidence of VanA-type Vancomycin-resistant Enterococci isolated from poultry meat and from fecal samples of humans in the community after discontinuation of Avoparcin Usage in Animal Husbandry. Microb. Drug Resist. 1999, 5, 45-52. [CrossRef]

45. Centers for Disease Control and Prevention. Nosocomial enterococci resistant to vancomycin-United States, 1989-MMWR. Morb. Mortal. Wkly. Rep. 1993, 42, 597-599.

46. Agersø, Y.; Hald, T.; Helwigh, B.; Høg, B.; Jensen, L.B.; Jensen, V.F.; Korsgaard, H.; Larsen, L.; Seyfarth, A.; Struve, T. DANMAP 2011-Use of Antimicrobial Agents and Occurrence of Antimicrobial Resistance in Bacteria from Food Animals, Food and Humans in Denmark; Statens Serum Institut Location: Copenhagen, Denmark, 2012.

47. Leinweber, H.; Alotaibi, S.M.; Overballe-Petersen, S.; Hansen, F.; Hasman, H.; Bortolaia, V.; Hammerum, A.M.; Ingmer, H. Vancomycin resistance in Enterococcus faecium isolated from Danish chicken meat is located on a pVEF4-like plasmid persisting in poultry for 18 years. Int. J. Antimicrob. Agents 2018, 52, 283-286. [CrossRef]

48. Birkegård, A.C.; Græsbøll, K.; Clasen, J.; Halasa, T.; Toft, N.; Folkesson, A. Continuing occurrence of vancomycin resistance determinants in Danish pig farms 20 years after removing exposure to avoparcin. Vet. Microbiol. 2019, 232, 84-88. [CrossRef] [PubMed]

49. Muloi, D.; Ward, M.J.; Pedersen, A.B.; Fèvre, E.M.; Woolhouse, M.E.; Van Bunnik, B.A. Are food animals responsible for transfer of antimicrobial-resistant Escherichia colior their resistance determinants to human populations? A Systematic Review. Foodborne Pathog. Dis. 2018, 15, 467-474. [CrossRef]

50. Johnson, J.R.; Kuskowski, M.A.; Menard, M.; Gajewski, A.; Xercavins, M.; Garau, J. Similarity between human and chicken Escherichia coli isolates in relation to Ciprofloxacin resistance status. J. Infect. Dis. 2006, 194, 71-78. [CrossRef]

51. Graziani, C.; Luzzi, I.; Corrò, M.; Tomei, F.; Parisi, G.; Giufrè, M.; Morabito, S.; Caprioli, A.; Cerquetti, M. Phylogenetic abckground and virulence genotype of Ciprofloxacin-susceptible and Ciprofloxacin-resistant Escherichia coli strains of human and avian origin. J. Infect. Dis. 2009, 199, 1209-1217. [CrossRef]

52. Xiong, W.; Sun, Y.; Zeng, Z. Antimicrobial use and antimicrobial resistance in food animals. Environ. Sci. Pollut. Res. 2018, 25, 18377-18384. [CrossRef]

53. Starr, M.P.; Reynolds, D.M. Streptomycin resistance of coliform bacteria from turkeys fed Streptomycin. Am. J. Public Heal. Nations Health 1951, 41, 1375-1380. [CrossRef]

54. Datta, N. Transmissible drug resistance in an epidemic strain of Salmonella typhimurium. J. Hyg. 1962, 60, 301-310. [CrossRef]

55. World Health Organization. High Levels of Antibiotic Resistance Found Worldwide, New Data Shows. Available online: https:/ / www.who.int/mediacentre/news/releases/2018/antibiotic-resistance-found/en/ (accessed on 17 June 2020).

56. Pöppe, J.; Bote, K.; Ramesh, A.; Murugaiyan, J.; Kuropka, B.; Kühl, M.; Johnston, P.; Roesler, U.; Makarova, O. Selection for resistance to a glyphosate-containing herbicide in does not result in a sustained activation of the tolerance response or increased cross-tolerance and cross-resistance to clinically important antibiotics. Appl. Environ. Microbiol. 2020, 86, e01204-e01220. [CrossRef]

57. Hatsuda, Y.; Ishizaka, T.; Koizumi, N.; Yasui, Y.; Saito, T.; Omotani, S.; Maki, S.; Teramachi, H.; Myotoku, M. Monitoring antimicrobial cross-resistance with cross-resistance rate correlation diagrams: Changes in antibiotic susceptibility of Pseudomonas aeruginosa due to hospital relocation. J. Clin. Pharm. Ther. 2021, 46, 395-407. [CrossRef]

58. Lautenbach, E.; Patel, J.B.; Bilker, W.B.; Edelstein, P.H.; Fishman, N.O. Extended-spectrum-Lactamase-producing Escherichia coli and Klebsiella pneumoniae: Risk factors for infection and impact of resistance on outcomes. Clin. Infect. Dis. 2001, 32, $1162-1171$. [CrossRef]

59. Carmeli, Y.; Troillet, N.; Karchmer, A.W.; Samore, M.H. Health and economic outcomes of antibiotic resistance in Pseudomonas aeruginosa. Arch. Intern. Med. 1999, 159, 1127-1132. [CrossRef] [PubMed]

60. Cosgrove, S.E.; Kaye, K.S.; Eliopoulous, G.M.; Carmeli, Y. Health and Economic outcomes of the emergence of third-generation Cephalosporin resistance in Enterobacter species. Arch. Intern. Med. 2002, 162, 185-190. [CrossRef]

61. O'Neill, J. Tackling Drug-Resistant Infections Globally: Final Report and Recommendations; Review on antimicrobial resistance; HM Government and the Wellcome Trust: London, UK, 2016.

62. Serra-Burriel, M.; Keys, M.; Campillo-Artero, C.; Agodi, A.; Barchitta, M.; Gikas, A.; Palos, C.; López-Casasnovas, G. Impact of multi-drug resistant bacteria on economic and clinical outcomes of healthcare-associated infections in adults: Systematic review and meta-analysis. PLOS ONE 2020, 15, e0227139. [CrossRef] [PubMed]

63. The World Bank. Drug-Resistant Infections: A Threat to Our Economic Future; World Bank: Washington, DC, USA, 2017.

64. Levin, A.S.; Barone, A.A.; Penço, J.; Santos, M.V.; Marinho, I.S.; Arruda, E.A.G.; Manrique, E.I.; Costa, S.F. Intravenous Colistin as therapy for nosocomial infections caused by multidrug-resistant Pseudomonas aeruginosa and Acinetobacter baumannii. Clin. Infect. Dis. 1999, 28, 1008-1011. [CrossRef] [PubMed] 
65. Liu, Y.-Y.; Wang, Y.; Walsh, T.R.; Yi, L.-X.; Zhang, R.; Spencer, J.; Doi, Y.; Tian, G.; Dong, B.; Huang, X.; et al. Emergence of plasmid-mediated colistin resistance mechanism MCR-1 in animals and human beings in China: A microbiological and molecular biological study. Lancet Infect. Dis. 2016, 16, 161-168. [CrossRef]

66. Ventola, C.L. The antibiotic resistance crisis: Part 1: Causes and threats. Pharm. Ther. 2015, 40, $277-283$.

67. Food and Drug Administration. Food and Agriculture Organisation of the United Nations. Available online: http://www.fao. org/faostat/en/\#data/CL (accessed on 5 April 2021).

68. Food and Drug Administration. Center for Veterinary Medicine. Summary Report on Antimicrobials Sold or Distributed for Use in Food-Producing Animals; Food and Drug Administration, Department of Health and Human Services: Silver Spring, MA, USA, $2014 ; 26 p$.

69. Lekshmi, M.; Ammini, P.; Kumar, S.; Varela, M.F. The food production environment and the development of antimicrobial resistance in human pathogens of animal origin. Microorganisms 2017, 5, 11. [CrossRef]

70. Chantziaras, I.; Boyen, F.; Callens, B.; Dewulf, J. Correlation between veterinary antimicrobial use and antimicrobial resistance in food-producing animals: A report on seven countries. J. Antimicrob. Chemother. 2014, 69, 827-834. [CrossRef]

71. Elliott, K.A.; Kenny, C.; Madan, J. A Global Treaty to Reduce Antimicrobial Use in Livestock; Center for Global Development: Washington, DC, USA, 2017.

72. Phillips, I. Withdrawal of growth-promoting antibiotics in Europe and its effects in relation to human health. Int. J. Antimicrob. Agents 2007, 30, 101-107. [CrossRef]

73. Brüssow, H. Adjuncts and alternatives in the time of antibiotic resistance and in-feed antibiotic bans. Microb. Biotechnol. 2017, 10, 674-677. [CrossRef]

74. Van Boeckel, T.P.; Brower, C.C.; Gilbert, M.; Grenfell, B.T.; Levin, S.A.S.; Robinson, T.P.; Teillant, A.A.; Laxminarayan, R.R. Global trends in antimicrobial use in food animals. Proc. Natl. Acad. Sci. USA 2015, 112, 5649-5654. [CrossRef] [PubMed]

75. Tan, L.T.-H.; Chan, K.-G.; Lee, L.-H. Application of bacteriophage in biocontrol of major foodborne bacterial pathogens. J. Mol. Biol. Mol. Imaging 2014, 1.

76. Letchumanan, V.; Chan, K.-G.; Pusparajah, P.; Saokaew, S.; Duangjai, A.; Goh, B.-H.; Ab Mutalib, N.-S.; Lee, L.-H. Insights into bacteriophage application in controlling Vibrio Species. Front. Microbiol. 2016, 7, 1114. [CrossRef]

77. Twort, F. An investigation on the nature of ultra-microscopic viruses. Lancet 1915, 186, 1241-1243. [CrossRef]

78. d'Hérelle, F. On an invisible microbe antagonistic to dysentery bacilli. Note by M. F. d'Herelle, presented by M. Roux. Comptes Rendus Academie des Sciences 1917. Res. Microbiol. 2007, 158, 553-554. [CrossRef]

79. Carrillo, C.L.; Atterbury, R.J.; El-Shibiny, A.; Connerton, P.L.; Dillon, E.; Scott, A.; Connerton, I.F. Bacteriophage therapy to reduce Campylobacter jejuni colonization of broiler chickens. Appl. Environ. Microbiol. 2005, 71, 6554-6563. [CrossRef]

80. Carvalho, C.M.; Gannon, B.W.; Halfhide, D.E.; Santos, S.B.; Hayes, C.M.; Roe, J.M.; Azeredo, J. The in vivo efficacy of two administration routes of a phage cocktail to reduce numbers of Campylobacter coli and Campylobacter jejuni in chickens. BMC Microbiol. 2010, 10, 232. [CrossRef]

81. Chinivasagam, H.N.; Estella, W.; Maddock, L.; Mayer, D.G.; Weyand, C.; Connerton, P.L.; Connerton, I.F. Bacteriophages to control Campylobacter in commercially farmed broiler chickens, in Australia. Front. Microbiol. 2020, 11, 632. [CrossRef]

82. Richards, P.J.; Connerton, P.L.; Connerton, I.F. Phage biocontrol of Campylobacter jejuni in chickens does not produce collateral effects on the gut microbiota. Front. Microbiol. 2019, 10, 476. [CrossRef]

83. Seo, B.-J.; Song, E.-T.; Lee, K.; Kim, J.-W.; Jeong, C.-G.; Moon, S.-H.; Son, J.S.; Kang, S.H.; Cho, H.-S.; Jung, B.Y.; et al. Evaluation of the broad-spectrum lytic capability of bacteriophage cocktails against various Salmonella serovars and their effects on weaned pigs infected with Salmonella Typhimurium. J. Vet. Med. Sci. 2018, 80, 851-860. [CrossRef] [PubMed]

84. Wall, S.K.; Zhang, J.; Rostagno, M.H.; Ebner, P.D. Phage therapy to reduce preprocessing Salmonella infections in market-weight Swine. Appl. Environ. Microbiol. 2009, 76, 48-53. [CrossRef] [PubMed]

85. Vaz, C.S.L.; Voss-Rech, D.; Alves, L.; Coldebella, A.; Brentano, L.; Trevisol, I.M. Effect of time of therapy with wild-type lytic bacteriophages on the reduction of Salmonella enteritidis in broiler chickens. Vet. Microbiol. 2020, 240, 108527. [CrossRef]

86. Clavijo, V.; Baquero, D.; Hernandez, S.; Farfan, J.; Arias, J.; Arévalo, A.; Donado-Godoy, P.; Vives-Flores, M. Phage cocktail SalmoFREE ${ }^{\circledR}$ reduces Salmonella on a commercial broiler farm. Poult. Sci. 2019, 98, 5054-5063. [CrossRef]

87. Borie, C.; Albala, I.; Sànchez, P.; Sánchez, M.L.; Ramírez, S.; Navarro, C.; Morales, M.A.; Retamales, A.J.; Robeson, J. Bacteriophage treatment Reduces Salmonella colonization of infected chickens. Avian Dis. 2008, 52, 64-67. [CrossRef]

88. Oliveira, A.; Sereno, R.; Azeredo, J. In vivo efficiency evaluation of a phage cocktail in controlling severe colibacillosis in confined conditions and experimental poultry houses. Vet. Microbiol. 2010, 146, 303-308. [CrossRef]

89. Miller, R.W.; Skinner, E.J.; Sulakvelidze, A.; Mathis, G.F.; Hofacre, C.L. Bacteriophage therapy for control of necrotic Enteritis of broiler chickens experimentally infected with Clostridium perfringens. Avian Dis. 2010, 54, 33-40. [CrossRef]

90. Kim, J.S.; Hosseindoust, A.; Lee, S.H.; Choi, Y.H.; Kim, M.J.; Lee, J.H.; Kwon, I.K.; Chae, B.J. Bacteriophage cocktail and multistrain probiotics in the feed for weanling pigs: Effects on intestine morphology and targeted intestinal coliforms and Clostridium. Animal 2017, 11, 45-53. [CrossRef] [PubMed]

91. Scott, A.E.; Timms, A.R.; Connerton, P.L.; Carrillo, C.L.; Radzum, K.A.; Connerton, I.F. Genome dynamics of Campylobacter jejuni in response to bacteriophage predation. PLOS Pathog. 2007, 3, e119. [CrossRef]

92. Gigante, A.; Atterbury, R.J. Veterinary use of bacteriophage therapy in intensively-reared livestock. Virol. J. 2019, 16, 1-9. [CrossRef] 
93. Colomer-Lluch, M.; Jofre, J.; Muniesa, M. Antibiotic resistance genes in the bacteriophage DNA fraction of environmental samples. PLoS ONE 2011, 6, e17549. [CrossRef]

94. Brabban, A.; Hite, E.; Callaway, T. Evolution of foodborne pathogens via temperate bacteriophage-mediated gene transfer. Foodborne Pathog. Dis. 2005, 2, 287-303. [CrossRef] [PubMed]

95. Enault, F.; Briet, A.; Bouteille, L.; Roux, S.; Sullivan, M.B.; Petit, M.-A. Phages rarely encode antibiotic resistance genes: A cautionary tale for virome analyses. ISME J. 2016, 11, 237-247. [CrossRef]

96. Wang, M.; Liu, P.; Zhou, Q.; Tao, W.; Sun, Y.; Zeng, Z. Estimating the contribution of bacteriophage to the dissemination of antibiotic resistance genes in pig feces. Environ. Pollut. 2018, 238, 291-298. [CrossRef] [PubMed]

97. Moak, M.; Molineux, I.J. Peptidoglycan hydrolytic activities associated with bacteriophage virions. Mol. Microbiol. 2004, 51, 1169-1183. [CrossRef] [PubMed]

98. Briers, Y.; Volckaert, G.; Cornelissen, A.; Lagaert, S.; Michiels, C.W.; Hertveldt, K.; Lavigne, R. Muralytic activity and modular structure of the endolysins of Pseudomonas aeruginosa bacteriophages ?KZ and EL. Mol. Microbiol. 2007, 65, 1334-1344. [CrossRef]

99. Rashel, M.; Uchiyama, J.; Ujihara, T.; Uehara, Y.; Kuramoto, S.; Sugihara, S.; Yagyu, K.; Muraoka, A.; Sugai, M.; Hiramatsu, K.; et al. Efficient elimination of multidrug-resistant Staphylococcus aureus by cloned lysin derived from bacteriophage $\varphi$ MR. J. Infect. Dis. 2007, 196, 1237-1247. [CrossRef]

100. Yoong, P.; Schuch, R.; Nelson, D.; Fischetti, V.A. Identification of a Broadly Active phage lytic enzyme with lethal activity against antibiotic-resistant Enterococcus faecalis and Enterococcus faecium. J. Bacteriol. 2004, 186, 4730-4739. [CrossRef]

101. Briers, Y.; Walmagh, M.; Van Puyenbroeck, V.; Cornelissen, A.; Cenens, W.; Aertsen, A.; Oliveira, H.; Azeredo, J.; Verween, G.; Pirnay, J.-P.; et al. Engineered endolysin-based "Artilysins" to combat multidrug-resistant gram-negative pathogens. mBio 2014, 5, e01379-14. [CrossRef]

102. Loeffler, J.M.; Djurkovic, S.; Fischetti, V.A. Phage lytic enzyme Cpl-1 as a novel antimicrobial for Pneumococcal bacteremia. Infect. Immun. 2003, 71, 6199-6204. [CrossRef] [PubMed]

103. Rodríguez, L.; Martínez, B.; Zhou, Y.; Rodríguez, A.; Donovan, D.M.; García, P. Lytic activity of the virion-associated peptidoglycan hydrolase HydH5 of Staphylococcus aureus bacteriophage vB_SauS-phiIPLA. BMC Microbiol. 2011, 11, 138. [CrossRef] [PubMed]

104. Swift, S.M.; Reid, K.P.; Donovan, D.M.; Ramsay, T.G. Thermophile lytic enzyme fusion proteins that target Clostridium perfringens. Antibiotics 2019, 8, 214. [CrossRef] [PubMed]

105. Rose, M.E.; Orlans, E. Immunoglobulins in the egg, embryo and young chick. Dev. Comp. Immunol. 1981, 5, 15-20. [CrossRef]

106. Rose, M.E.; Orlans, E.; Buttress, N. Immunoglobulin classes in the hen's egg: Their segregation in yolk and white. Eur. J. Immunol. 1974, 4, 521-523. [CrossRef] [PubMed]

107. Yegani, M.; Korver, D. Application of egg yolk antibodies as replacement for antibiotics in poultry. World's Poult. Sci. J. 2010, 66, 27-38. [CrossRef]

108. Carlander, D.; Wilhelmson, M.; Larsson, A. Immunoglobulin Y levels in egg yolk from three chicken genotypes. Food Agric. Immunol. 2003, 15, 35-40. [CrossRef]

109. Li, C.; Ren, H.; Schade, R.; Zhang, X. A novel and efficient immunoglobulin Y extraction method using poloxamer-polyethylene glycol. Prep. Biochem. Biotechnol. 2017, 47, 739-743. [CrossRef]

110. Jiang, Z.; Jiang, X.; Li, C.; Xue, H.; Zhang, X. Development of an IgY antibody-based immunoassay for the screening of the CYP2E1 Inhibitor/Enhancer from herbal medicines. Front. Pharmacol. 2016, 7, 502. [CrossRef]

111. Karamzadeh-Dehaghani, A.; Towhidi, A.; Zhandi, M.; Mojgani, N. Specific chicken egg yolk antibodies against enterotoxigenic Escherichia coli K99 in serum and egg yolk of immunized laying hens. Iran. J. Appl. Anim. Sci. 2020, 10, $155-161$.

112. Amro, W.A.; Al-Qaisi, W.; Al-Razem, F. Production and purification of IgY antibodies from chicken egg yolk. J. Genet. Eng. Biotechnol. 2018, 16, 99-103. [CrossRef] [PubMed]

113. Salim, H.M.; Huque, K.S.; Kamaruddin, K.M.; Haque Beg, A. Global restriction of using antibiotic growth promoters and alternative strategies in poultry production. Sci. Prog. 2018, 101, 52-75. [CrossRef]

114. Gürtler, M.; Methner, U.; Kobilke, H.; Fehlhaber, K. Effect of orally administered egg yolk antibodies on Salmonella enteritidis Contamination of Hen's Eggs. J. Vet. Med. Ser. B 2004, 51, 129-134. [CrossRef]

115. Vandeputte, J.; Martel, A.; Canessa, S.; Van Rysselberghe, N.; De Zutter, L.; Heyndrickx, M.; Haesebrouck, F.; Pasmans, F.; Garmyn, A. Reducing Campylobacter jejuni colonization in broiler chickens by in-feed supplementation with hyperimmune egg yolk antibodies. Sci. Rep. 2019, 9, 1-10. [CrossRef]

116. Sugita-Konishi, Y.; Shibata, K.; Yun, S.S.; Hara-Kudo, Y.; Yamaguchi, K.; Kumagai, S. Immune functions of immunoglobulin $\mathrm{Y}$ isolated from egg yolk of hens immunized with various infectious bacteria. Biosci. Biotechnol. Biochem. 1996, 60, 886-888. [CrossRef] [PubMed]

117. Schade, R.; Staak, C.; Hendriksen, C.; Erhard, M.; Hugl, H.; Koch, G.; Larsson, A.; Pollmann, W.; Van Regenmortel, M.; Rijke, E.; et al. The production of avian (egg yolk) antibodies: IgY. Altern. Lab. Anim. 1996, 24, 925-934. [CrossRef]

118. Casadevall, A.; Scharff, M.D. Serum therapy revisited: Animal models of infection and development of passive antibody therapy. Antimicrob. Agents Chemother. 1994, 38, 1695-1702. [CrossRef] [PubMed]

119. Hancock, R.E.; Lehrer, R. Cationic peptides: A new source of antibiotics. Trends Biotechnol. 1998, 16, 82-88. [CrossRef]

120. Chee, P.Y.; Mang, M.; Lau, E.S.; Tan, L.T.-H.; He, Y.-W.; Lee, W.-L.; Pusparajah, P.; Chan, K.-G.; Lee, L.-H.; Goh, B.-H. Epinecidin-1, an Antimicrobial peptide derived from grouper (Epinephelus coioides): Pharmacological activities and applications. Front. Microbiol. 2019, 10, 2631. [CrossRef] 
121. Kokryakov, V.N.; Harwig, S.S.; Panyutich, E.A.; Shevchenko, A.A.; Aleshina, G.M.; Shamova, O.V.; Korneva, H.A.; Lehrer, R.I. Protegrins: Leukocyte antimicrobial peptides that combine features of corticostatic defensins and tachyplesins. FEBS Lett. 1993, 327, 231-236. [CrossRef]

122. Cotter, P.D.; Ross, R.P.; Hill, C. Bacteriocins a viable alternative to antibiotics? Nat. Rev. Genet. 2013, 11, 95-105. [CrossRef]

123. Lin, L.; Nonejuie, P.; Munguia, J.; Hollands, A.; Olson, J.; Dam, Q.; Kumaraswamy, M.; Rivera, H.; Corriden, R.; Rohde, M.; et al. Azithromycin synergizes with cationic antimicrobial peptides to exert bactericidal and therapeutic activity against highly multidrug-resistant gram-negative bacterial pathogens. EBioMedicine 2015, 2, 690-698. [CrossRef]

124. Ageitos, J.; Sánchez-Pérez, A.; Calo-Mata, P.; Villa, T. Antimicrobial peptides (AMPs): Ancient compounds that represent novel weapons in the fight against bacteria. Biochem. Pharmacol. 2017, 133, 117-138. [CrossRef] [PubMed]

125. Wu, S.; Wang, J.; Zhu, L.; Ren, H.; Yang, X. A novel apidaecin Api-PR19 synergizes with the gut microbial community to maintain intestinal health and promote growth performance of broilers. J. Anim. Sci. Biotechnol. 2020, 11, 1-18. [CrossRef]

126. Wang, X.; Zhu, M. Effect of antibacterial peptide cecropin B on growth-enhancing and immunological functionin in chickens. J. Ningxia Medical Univ. 2010, 1. [CrossRef]

127. Lu, Y.; Wang, S.; Wang, K. The effects of antibiotic peptide S807 on improving the production performance in broilers. Guangdong J. Anim. Vet. Sci. 2010, 4. [CrossRef]

128. Grilli, E.; Messina, M.R.; Catelli, E.; Morlacchini, M.; Piva, A. Pediocin A improves growth performance of broilers challenged with Clostridium perfringens. Poult. Sci. 2009, 88, 2152-2158. [CrossRef]

129. Udompijitkul, P.; Paredes-Sabja, D.; Sarker, M.R. Inhibitory Effects of nisin against Clostridium perfringens food poisoning and nonfood-borne isolates. J. Food Sci. 2011, 77, M51-M56. [CrossRef]

130. Crost, E.H.; Ajandouz, E.H.; Villard, C.; Geraert, P.A.; Puigserver, A.; Fons, M. Ruminococcin C, a new anti-Clostridium perfringens bacteriocin produced in the gut by the commensal bacterium Ruminococcus gnavus E1. Biochimie 2011, 93, 1487-1494. [CrossRef]

131. Pérez-Bosque, A.; Polo, J.; Torrallardona, D. Spray dried plasma as an alternative to antibiotics in piglet feeds, mode of action and biosafety. Porc. Health Manag. 2016, 2, 16. [CrossRef] [PubMed]

132. Marr, A.K.; Gooderham, W.J.; Hancock, R.E. Antibacterial peptides for therapeutic use: Obstacles and realistic outlook. Curr. Opin. Pharmacol. 2006, 6, 468-472. [CrossRef] [PubMed]

133. Daneshmand, A.; Kermanshahi, H.; Sekhavati, M.H.; Javadmanesh, A.; Ahmadian, M.; Alizadeh, M.; Aldawoodi, A. Effects of cLFchimera peptide on intestinal morphology, integrity, microbiota, and immune cells in broiler chickens challenged with necrotic enteritis. Sci. Rep. 2020, 10, 1-11. [CrossRef]

134. Li, B.; Yang, N.; Wang, X.; Hao, Y.; Mao, R.; Li, Z.; Wang, Z.; Teng, D.; Wang, J. An enhanced variant designed from DLP4 cationic peptide against Staphylococcus aureus CVCC Front. Microbiol. 2020, 11, 1057. [CrossRef]

135. Wang, S.; Zeng, X.; Yang, Q.; Qiao, S. Antimicrobial peptides as potential alternatives to antibiotics in food animal industry. Int. J. Mol. Sci. 2016, 17, 603. [CrossRef]

136. Tan, W.-S.; Law, J.W.-F.; Letchumanan, V.; Chan, K.-G. Decoding the mystery of how bacteria "talk": Among Gram-negative microorganisms. Prog. Microbes Mol. Biol. 2019, 2, 1-7. [CrossRef]

137. Tan, W.-S.; Law, J.W.-F.; Law, L.N.-S.; Letchumanan, V.; Chan, K.-G. Insights into quorum sensing (QS): QS-regulated biofilm and inhibitors. Prog. Microbes Mol. Biol. 2020, 3, 3. [CrossRef]

138. Nealson, K.H.; Platt, T.; Hastings, J.W. Cellular Control of the Synthesis and Activity of the Bacterial Luminescent System. J. Bacteriol. 1970, 104, 313-322. [CrossRef]

139. Eholm, A.; Vikström, E. Quorum sensing communication between bacteria and human cells: Signals, targets, and functions. Front. Plant. Sci. 2014, 5, 309. [CrossRef]

140. Bzdrenga, J.; Daudé, D.; Rémy, B.; Jacquet, P.; Plener, L.; Elias, M.; Chabrière, E. Biotechnological applications of quorum quenching enzymes. Chem. Interact. 2017, 267, 104-115. [CrossRef]

141. Manefield, M.; Rasmussen, T.B.; Henzter, M.; Andersen, J.B.; Steinberg, P.; Kjelleberg, S.; Givskov, M. Halogenated furanones inhibit quorum sensing through accelerated LuxR turnover. Microbiology 2002, 148, 1119-1127. [CrossRef] [PubMed]

142. Hentzer, M.; Givskov, M. Pharmacological inhibition of quorum sensing for the treatment of chronic bacterial infections. J. Clin. Investig. 2003, 112, 1300-1307. [CrossRef]

143. Dong, Y.-H.; Xu, J.-L.; Li, X.-Z.; Zhang, L.-H. AiiA, an enzyme that inactivates the acylhomoserine lactone quorum-sensing signal and attenuates the virulence of Erwinia carotovora. Proc. Natl. Acad. Sci. USA 2000, 97, 3526-3531. [CrossRef] [PubMed]

144. Dong, Y.-H.; Zhang, X.-F.; Xu, J.-L.; Zhang, L.-H. Insecticidal Bacillus thuringiensis silences Erwinia carotovora virulence by a new form of microbial antagonism, signal interference. Appl. Environ. Microbiol. 2004, 70, 954-960. [CrossRef]

145. Vinoj, G.; Vaseeharan, B.; Thomas, S.; Spiers, A.J.; Shanthi, S. Quorum-quenching activity of the AHL-lactonase from Bacillus licheniformis DAHB1 inhibits Vibrio biofilm formation in vitro and reduces shrimp intestinal colonisation and mortality. Mar. Biotechnol. 2014, 16, 707-715. [CrossRef]

146. Cao, Y.; He, S.; Zhou, Z.; Zhang, M.; Mao, W.; Zhang, H.; Yao, B. Orally administered thermostableN-Acyl homoserine lactonase from Bacillus sp. strain AI96 attenuates Aeromonas hydrophila infection in Zebrafish. Appl. Environ. Microbiol. 2012, 78, 1899-1908. [CrossRef]

147. Afriat, L.; Roodveldt, C.; Manco, G.; Tawfik, D.S. The latent promiscuity of newly identified microbial lactonases is linked to a recently diverged phosphotriesterase. Biochemistry 2006, 45, 13677-13686. [CrossRef] 
148. Hiblot, J.; Bzdrenga, J.; Champion, C.; Chabriere, E.; Elias, M. Crystal structure of VmoLac, a tentative quorum quenching lactonase from the extremophilic crenarchaeon Vulcanisaeta moutnovskia. Sci. Rep. 2015, 5, 8372. [CrossRef]

149. Merone, L.; Mandrich, L.; Rossi, M.; Manco, G. A thermostable phosphotriesterase from the archaeon Sulfolobus solfataricus: Cloning, overexpression and properties. Extremophiles 2005, 9, 297-305. [CrossRef]

150. Hiblot, J.; Gotthard, G.; Chabriere, E.; Elias, M. Structural and enzymatic characterization of the lactonase SisLac from Sulfolobus islandicus. PLoS ONE 2012, 7, e47028. [CrossRef]

151. Del Vecchio, P.; Elias, M.; Merone, L.; Graziano, G.; Dupuy, J.; Mandrich, L.; Carullo, P.; Fournier, B.; Rochu, D.; Rossi, M.; et al. Structural determinants of the high thermal stability of SsoPox from the hyperthermophilic archaeon Sulfolobus solfataricus. Extremophiles 2009, 13, 461-470. [CrossRef] [PubMed]

152. Tan, L.T.-H.; Chan, K.-G.; Lee, L.-H.; Goh, B.-H. Streptomyces bacteria as potential probiotics in aquaculture. Front. Microbiol. 2016, 7, 79. [CrossRef]

153. Fuller, R. Probiotics in man and animals. J. Appl. Bacteriol. 1989, 66, 365-378. [PubMed]

154. Patel, S.G.; Raval, A.P.; Bhagwat, S.R.; Sadrasaniya, D.A.; Patel, A.P.; Joshi, S.S. Effects of probiotics supplementation on growth performance, feed conversion ratio and economics of broilers. J. Anim. Res. 2015, 5, 155. [CrossRef]

155. Simon, O.; Jadamus, A.; Vahjen, W. Probiotic feed additives-Effectiveness and expected modes of action. J. Anim. Feed. Sci. 2001, 10, 51-67. [CrossRef]

156. Tellez, G.; Pixley, C.; Wolfenden, R.; Layton, S.; Hargis, B. Probiotics/direct fed microbials for Salmonella control in poultry. Food Res. Int. 2012, 45, 628-633. [CrossRef]

157. Mingmongkolchai, S.; Panbangred, W. Bacillusprobiotics: An alternative to antibiotics for livestock production. J. Appl. Microbiol. 2018, 124, 1334-1346. [CrossRef]

158. Morishita, T.Y.; Aye, P.P.; Harr, B.S.; Cobb, C.W.; Clifford, J.R. Evaluation of an Avian-specific probiotic to reduce the colonization and shedding of Campylobacter jejuni in broilers. Avian Dis. 1997, 41, 850-855. [CrossRef]

159. Bozdogan, B.; Galopin, S.; Gerbaud, G.; Courvalin, P.; Leclercq, R. Chromosomal aadD2 encodes an aminoglycoside nucleotidyltransferase in Bacillus clausii. Antimicrob. Agents Chemother. 2003, 47, 1343-1346. [CrossRef]

160. Girlich, D.; Leclercq, R.; Naas, T.; Nordmann, P. Molecular and biochemical characterization of the chromosome-encoded class A ß-lactamase BCL-1 from Bacillus clausii. Antimicrob. Agents Chemother. 2007, 51, 4009-4014. [CrossRef]

161. Galopin, S.; Cattoir, V.; Leclercq, R.; Galopin, S. A chromosomal chloramphenicol acetyltransferase determinant from a probiotic strain of Bacillus clausii. FEMS Microbiol. Lett. 2009, 296, 185-189. [CrossRef]

162. Gibson, G.R.; Roberfroid, M.B. Dietary modulation of the human colonic microbiota: Introducing the concept of prebiotics. J. Nutr. 1995, 125, 1401-1412. [CrossRef]

163. de Vrese, M.; Schrezenmeir, J. Probiotics, Prebiotics, and Synbiotics. In Food Biotechnol; Stahl, U., Donalies, U.E., Nevoigt, E., Eds.; Springer: Berlin/Heidelberg, Germany, 2008; Volume 111, pp. 1-66.

164. Cheng, Y.; Chen, Y.; Li, X.; Yang, W.; Wen, C.; Kang, Y.; Wang, A.; Zhou, Y. Effects of synbiotic supplementation on growth performance, carcass characteristics, meat quality and muscular antioxidant capacity and mineral contents in broilers. J. Sci. Food Agric. 2017, 97, 3699-3705. [CrossRef] [PubMed]

165. Mousavi, S.A.; Seidavi, A.; Dadashbeiki, M.; Kilonzo-Nthenge, A.; Nahashon, S.; Laudadio, V.; Tufarelli, V. Effect of a synbiotic (Biomin ${ }^{\circledR} \mathrm{IMBO}$ ) on growth performance traits of broiler chickens. Eur. Poult. Sci. 2015, 79. [CrossRef]

166. Pruszynska-Oszmalek, E.; Kolodziejski, P.A.; Stadnicka, K.; Sassek, M.; Chalupka, D.; Kuston, B.; Nogowski, L.; Mackowiak, P.; Maiorano, G.; Jankowski, J.; et al. In ovo injection of prebiotics and synbiotics affects the digestive potency of the pancreas in growing chickens. Poult. Sci. 2015, 94, 1909-1916. [CrossRef]

167. Collins, J.W.; La Ragione, R.M.; Woodward, M.J.; Searle, L.E.J. Application of prebiotics and probiotics in livestock. In Prebiotics and Probiotics Science and Technology; Metzler, J.B., Ed.; Springer: New York, NY, USA, 2009; pp. 1123-1192. ISBN 978-0-387-79057-2. [CrossRef]

168. Hinc, K.; Ghandili, S.; Karbalaee, G.; Shali, A.; Noghabi, K.A.; Ricca, E.; Ahmadian, G. Efficient binding of nickel ions to recombinant Bacillus subtilis spores. Res. Microbiol. 2010, 161, 757-764. [CrossRef] [PubMed]

169. Potot, S.; Serra, C.R.; Henriques, A.O.; Schyns, G. Display of recombinant proteins on Bacillus subtilis spores, using a coatassociated enzyme as the carrier. Appl. Environ. Microbiol. 2010, 76, 5926-5933. [CrossRef]

170. Ning, D.; Leng, X.; Li, Q.; Xu, W. Surface-displayed VP28 on Bacillus subtilis spores induce protection against white spot syndrome virus in crayfish by oral administration. J. Appl. Microbiol. 2011, 111, 1327-1336. [CrossRef] [PubMed]

171. Kim, J.-S.; Cho, D.-H.; Park, M.; Chung, W.-J.; Shin, D.; Ko, K.S.; Kweon, D.-H. CRISPR/Cas9-mediated re-sensitization of antibiotic-resistant Escherichia coli harboring extended-spectrum-lactamases. J. Microbiol. Biotechnol. 2016, 26, 394-401. [CrossRef]

172. Shabbir, M.A.B.; Wu, Q.; Mahmood, S.; Sajid, A.; Maan, M.K.; Ahmed, S.; Naveed, U.; Hao, H.; Yuan, Z. CRISPR-cas system: Biological function in microbes and its use to treat antimicrobial resistant pathogens. Ann. Clin. Microbiol. Antimicrob. 2019, 18, 1-9. [CrossRef]

173. Ling, L.L.; Schneider, T.; Peoples, A.J.; Spoering, A.L.; Engels, I.; Conlon, B.P.; Mueller, A.; Schäberle, T.F.; Hughes, D.E.; Epstein, S.; et al. A new antibiotic kills pathogens without detectable resistance. Nature 2015, 517, 455-459. [CrossRef] [PubMed] 